\title{
Variations in Primary Teachers' Responses and Development during Three Major Science In- Service Programmes
}

Tina Jarvis ${ }^{* 1}$, Anthony Pell ${ }^{2}$ and Philip Hingley ${ }^{3}$

$\propto$ This paper reports on how different types of teachers responded to in-service aimed at developing investigative-based science education (IBSE) in primary schools, and the extent to which they applied their new skills in the classroom. Common items from evaluation questionnaires allowed data to be combined from three major in-service programmes. Using complete data sets from 120 teachers, cluster analysis enabled three teacher types to be identified: a small group of 'science unsures', with low attitude scores and little confidence, who showed no response to the innovation; 'holistic improvers', who showed the largest improvement in science teaching confidence; and 'high level, positive progressives', who were very positive to science teaching throughout and showed gains in confidence in teaching physics and chemistry, as well as in demonstrating the relevance of science to their pupils. Taking account of these teacher types alongside interviews and observations, nine developmental stages in how teachers apply their new expertise in the classroom and the whole school are suggested. Major factors influencing application in the classroom are the teachers' initial science knowledge and pedagogical expertise, and motivating feedback to teachers when pupils responded positively to the innovation. Assessing teachers' initial level of subject knowledge and science pedagogical expertise to inform the approach and amount of in-service provision is important. Subsequent mentoring as well as support from the school principal when teachers first try IBSE with pupils promotes successful implementation in the classroom.

1 *Corresponding author: School of Education, University of Leicester, 21 University Road, Leicester LE1 7RF

jar@leicester.ac.uk

2 University of Leicester UK

3 University of Leicester UK 
Keywords: IBSE, In-service, Investigative-based science education, Motivation, Primary education

\section{Introduction}

There is a need to overcome both the shortage of scientists and technologists in Europe that are able to compete in a world market and to enable young people to become informed citizens. The European Commission appointed High Level Group (Gago) reported in 2004 that there needs to be an increase of $\mathbf{1 . 2}$ million people involved in research and development in science, engineering and technology in Europe. Education systems would therefore need to increase their capacity dramatically. However, generally the European countries did not show high ratings for pupils' achievement or attitudes in the 2007 TIMSS report (Martin et al., 2008).

Osborne and Dillon (2008) maintain that the needed increase in scientists can only be achieved by increasing the quality of the experience of science education for the majority of school pupils and broadening its relevance and appeal. They argue that this should start before pupils reach 14 years old because most students develop their attitudes towards science as a subject before that age. This is particularly important because many latent scientists appear to make early decisions about their careers (Blatchford, 1992; Woolnough, 1990). Indeed, action needs to be taken in primary schools where generally pupils do have a positive view of science but there are signs that their enthusiasm is already declining as they get older (Pell \& Jarvis, 2001; Woodward \& Woodward, 1998).

Good and confident science teaching in the primary school is crucial as there is evidence that there is a relationship between teacher confidence and attitudes with the attitudes and attainment of their pupils (den Brook et al., 2005; Germann, 1988). Teachers with low confidence cope by only teaching the minimum required; focusing on aspects they feel more confident in, usually biology; using prescriptive texts; underplaying questioning and discussion; and avoiding practical work or only doing very simple practical work that uses very basic equipment. When these coping strategies become the norm, pupils' attainment will be limited (Harlen \& Holroyd, 1997; Lee, 1995, Osborne $\&$ Simon, 1996) and their attitudes are likely to be reduced (She \& Fisher, 2002). 
Over the past 10 years, three major science in-service programmes for primary teachers, based on very similar principles, have been evaluated with respect to how the teachers' self-confidence in science knowledge and pedagogy changed over time as well as how they applied their new expertise in the classroom. The intention was to identify factors that promoted improved practice in the classroom.

The AstraZeneca Science Teaching Trust in-service programme, with 70 primary teachers and focused on developing investigative skills, was run in Leicester, England between 1999 and 2000 (Jarvis et al., 2003; Jarvis \& Pell, 2002, 2004). In the same city, a schoolbased in-service programme was provided for all 11 teachers of the Oak Hill Primary Schooli (2005-2006). Most recently, Pollen \& Seed Cities for Science, a community approach to the sustainable growth of science education in Europe (2007-2009), also set out to develop innovative hands-on investigative primary science. Data were collected from 765 teachers in 10 of the countries involved in Pollen. As the questionnaires used for the evaluation of each project had common items, it has been possible explore whether there were similarities in teacher response in all three projects.

The design of the three in-service programmes all took account of Joyce and Showers (1980) suggested factors of what makes effective training; namely, that training programmes should have five parts: theory (such as constructivism and the need for hands-on science); modelling or demonstration of pedagogy; practice under simulated conditions to try out a new skill with peers or small groups of children; structured feedback through self-study, peers or mentors; and supported classroom application. The training programmes ran over a period of at least one year, as a significant amount of research indicates that short courses have limited impact. A generative and constructivist approach to learning was taken, whereby learners were given personally relevant material and required to take an active part in the learning process (Glaserfeld, 1995; Wittrock, 1994). In each programme the main objective was to develop hands-on Inquiry-Based Science Education (IBSE), i.e., the intentional process of diagnosing problems, critiquing experiments and distinguishing alternatives, planning investigations, researching conjectures, searching for information, constructing models, debating with peers and forming coherent arguments (Rocard, 2008). The programmes set out to assist teachers to develop all of these

${ }^{i}$ Pseudonyms are given for individual schools and teachers. 
facets of IBSE, with the fundamental intention of developing science knowledge and concepts, as advocated by the USA Board of Education of the National Research Council (Duschl et al., 2007).

Despite the fact that the programmes were designed to take account of a great deal of research on factors that make good in-service training, the experience of the teachers and their pupils varied. This variation appeared to be partly related to the teachers' initial self-confidence in teaching science and their attitudes towards science. Teaching self-confidence might also be described as their efficacy belief (Park \& Oliver, 2007), which is a judgement of teachers' ability to bring about the desired outcomes of their pupils' participation and learning. This self-efficacy is considered to have important influence on teachers' behaviour and related student achievement and motivation (Bandura, 1977; Tschannen-Moran \& Hoy, 2001).

Writers about self-efficacy point out that teachers pursue activities and situations in which they feel competent and avoid those in which they doubt their ability to perform successfully. Guskey's (1988) research indicates that higher teacher efficacy results in a greater willingness to try new teaching strategies, while those who have lower levels of self-efficacy appear to be the least receptive to training and new ideas. In other words, those needing in-service are the least likely to want to be involved. Therefore, teachers who volunteered to be part of programmes such as Pollen may be more likely to respond to training compared to teachers who were required to join the AstraZeneca and Oak Hill programmes because they had difficulties teaching science. Therefore, part of this research explored teachers' self-confidence in science knowledge and skills before and after in-service.

Once teachers join an in-service programme there is then an interactive relationship between success in learning, perceptions of self and motivation. Achievement fosters a positive view of self, which motivates and prompts further learning (Stein \& Wang, 1988). Taking this into account, Stein and Wang suggest that in-service needs to foster teachers' interest in maintaining innovative school improvement and their commitment to do so. They write that teachers need monitored support for the on-going use of new knowledge in the classroom, with feedback on their progress in order to enhance their self-efficacy. Researchers consider that this feedback is generally provided by in-service trainers, school managers and positive results in pupil outcomes. Guskey (1986) states that change in teachers' attitudes takes place primarily after in-service and when some change in student learning has 
been evidenced. Consequently another element of this research was to explore if and how teachers implemented new ideas in their classroom, introduced during in-service, as well as the extent that school-based factors influenced change. In summary this research explored:

- How different teachers responded to in-service with respect to their self-confidence in science knowledge and pedagogy;

- The relationship between implementation in the classroom and teachers' self-confidence, science knowledge and pedagogy; and

- $\quad$ Other related factors that influenced the quality and speed of implementation of new practice in the classroom.

\section{Method}

\section{Sample}

The AstraZeneca Project involved 31 schools, 70 teachers and 1878 pupils aged 6-12 in Leicester, England (1999-2000). The schools had intakes from socially deprived areas and were underperforming in national science tests and/or were identified in government reports as having science as a weakness. All of the teachers took a ten-day course (spread over six months) on developing and assessing investigations. It covered developing open-ended investigations in the areas of electricity, melting, evaporation and dissolving, and friction. Teachers and pupils completed attitude questionnaires before the in-service and afterwards, in July 2000.

Eleven teachers from Oak Hill primary school, with over 300 pupils in Leicester, had an in-service programme after the AstraZeneca Project had finished. The teachers had not taken part in the previous project. Most of them had very low levels of competence and self-confidence in teaching science. Following paired or individual interviews to identify personal needs, they were given intensive in-service, in groups of two to four, aimed at developing pupils' investigative skills directly related to the science concepts currently being taught in the classes. There were 10 two-hour in-service sessions during 2005-2006. Most of the teachers had two sessions, but a few teachers had three. Again teachers completed attitude tests before and after the in-service.

During 2007 - 2009 data was collected from 420 teachers from 10 countries: Brussels (Belgium), Leicester (England), Tartu (Estonia), Saint-Etienne (France), Berlin (Germany), Vac (Hungary), Perugia (Italy), Loures-Sacavem (Portugal), Ljubljana (Slovenia) and Stockholm 
(Sweden) who were taking part in the Pollen project. This project involved one 'seed' city in each country over $3^{1 / 2}$ years. Every 'seed' city had the aim of promoting practical investigative work while making use of local organisations, industries and facilities. Teachers were given several training sessions focused on developing investigative skills. Most teachers received between 20 and 40 hours of training per year. Support was also provided by written units of study with guidance for practical activities. For example, the Portuguese had 22 learning units of practical ideas and pedagogical advice on a website. In a number of cases these units were also supported by kit boxes with all of the equipment needed for a class to carry out the activities.

\section{Instruments and research design}

\section{Questionnaire items common to all three projects were used for this research.}

Additional qualitative data were collected from observations and interviews of all of the Oak Hill teachers; several classroom observations of most of the English Pollen teachers; interviews of 33 teachers from Sweden, Germany and England participating in the Pollen project; and interviews of Pollen trainers and coordinators. English pupils involved in all of the projects also completed pre-attitude and postattitude questionnaires at the same time as their teachers. These additional data provide supportive information and indications of teachers' development with regard to the application of their new knowledge in the classroom.

All three project questionnaires were based on an instrument with a science attitude scale of 49 items with 0.96 overall reliability comprising six sub-scales (Pell \& Jarvis, 2003). The questionnaires asked for:

- $\quad$ personal information, such as size of class and years of experience as a teacher;

- $\quad$ responses to a 5-point Likert scale asking for teachers' selfconfidence in teaching their home language, mathematics, information technology, as well as science, where a score of five indicates the teacher feels very confident with no problems and a score of one indicates the teacher feels that he/she is not confident at all and needs more help with this.

- A similar 5-point Likert scale probed self-confidence in teaching biology, chemistry, physics and investigations; and there were 
- 5-point Likert statements probing attitudes towards various aspects of teaching science.

All but one of the confidence items were common to all three projects. One missing item on the Pollen confidence items means that single rather than composite scores have to be compared. A number of the attitudinal statements were adapted in the Pollen project to clarify statements that might have been understood in different ways in different countries. There were also items about working in the science community, which was an additional focus of the in-service training in the Pollen project. Once these are removed, there are 28 items that are common to all three projects with occasional very minor rewording.

\section{Results}

Factor analysis of the 28 items provides five coherent scales, which were built around the 20 strongest loading items that tested for practical Alpha reliability greater than 0.70, (Aron \& Aron, 1999; Youngman, 1979), can be seen in Table 1 . The low reliability of the twoitem Testing factor is unsurprising and inferences drawn from scores should be treated with caution. The remaining 8 unallocated items (see Table 2) form a further two minor factors but these are too weak for practical use. The five main factors are:

$1 \quad$ Social dimension to science learning, which indicates teachers' valuation of pupil collaboration in learning about science in a wider social context. This unidimensional factor accounts for $67 \%$ of the total variance of its items.

2 Continuous teacher professional development, which shows how much teachers value support for their own professional development ( $69 \%$ of the total variance of its items).

3 Testing for assessing the success of lessons and pupils' learning has a factor that accounts for $71 \%$ of the total variance of its two items.

4 Quality support to science learners gives a view of how teachers value the importance of strategies for building up science understanding. A second factor analysis of the scores from just the seven items in this scale shows that the factor is unidimensional, though weak, accounting for just $41 \%$ of the item variance of its items. 
5 Observational, experimental science focuses on the importance of developing investigational skills. The factor analysis of the scores from these four items also shows that the factor is unidimensional. It accounts for $55 \%$ of the variance of its items.

Table 1. Factors from the common attitudinal items $(n=327)$

\begin{tabular}{|c|c|c|}
\hline Factor & $\begin{array}{l}\text { Questionnaire items: Teachers' views of how } \\
\text { important it is to: }\end{array}$ & $\begin{array}{l}\text { Corrected } \\
\text { Item-Total } \\
\text { Correlation }\end{array}$ \\
\hline \multirow{3}{*}{$\begin{array}{l}\text { Social } \\
\text { dimension to } \\
\text { science learning } \\
\text { Alpha }=0.74\end{array}$} & Link new science learning to everyday experiences & 0.53 \\
\hline & $\begin{array}{l}\text { Show pupils how classroom learning relates to the } \\
\text { outside world }\end{array}$ & 0.65 \\
\hline & Encourage pupils to learn from each other & 0.54 \\
\hline \multirow{3}{*}{$\begin{array}{l}\text { Continuous } \\
\text { teacher } \\
\text { professional } \\
\text { development } \\
\text { Alpha }=0.76\end{array}$} & $\begin{array}{l}\text { Change learning materials to keep up with latest } \\
\text { developments }\end{array}$ & 0.55 \\
\hline & Take in-service courses on science knowledge & 0.72 \\
\hline & Take in-service courses on how to teach science & 0.53 \\
\hline \multirow{2}{*}{$\begin{array}{l}\text { Testing } \\
\text { Alpha }=0.62\end{array}$} & $\begin{array}{l}\text { Design tests to give information on how successful } \\
\text { the lesson was }\end{array}$ & 0.46 \\
\hline & $\begin{array}{l}\text { Use tests that require pupils to use their learning in } \\
\text { a new situation }\end{array}$ & 0.46 \\
\hline \multirow{7}{*}{$\begin{array}{l}\text { Quality support } \\
\text { for science } \\
\text { learners } \\
\text { Alpha }=0.75\end{array}$} & $\begin{array}{l}\text { Give each science lesson a clear introduction and } \\
\text { conclusion that summarises the learning }\end{array}$ & 0.37 \\
\hline & $\begin{array}{l}\text { Explain to pupils why their science activity is } \\
\text { important }\end{array}$ & 0.52 \\
\hline & Expect pupils to use scientific words correctly & 0.49 \\
\hline & Provide reference sources for pupils to use & 0.51 \\
\hline & Encourage and help pupils to write notes & 0.41 \\
\hline & Relate pupils' learning to science of the past & 0.49 \\
\hline & $\begin{array}{l}\text { Relate each new idea (concept) to ones that pupils } \\
\text { have already learnt }\end{array}$ & 0.52 \\
\hline \multirow{4}{*}{$\begin{array}{l}\text { Observational, } \\
\text { experimental } \\
\text { science } \\
\text { Alpha }=0.73\end{array}$} & $\begin{array}{l}\text { Encourage pupils to make careful observations, } \\
\text { repeating them if necessary }\end{array}$ & 0.47 \\
\hline & Help pupils to generalise from observations & 0.54 \\
\hline & Encourage pupils to plan their own investigations & 0.55 \\
\hline & $\begin{array}{l}\text { Help pupils to recognise and control variables inan } \\
\text { experiment }\end{array}$ & 0.51 \\
\hline
\end{tabular}




\section{Confidence and attitudinal changes after in-service}

When scores are pooled across the three projects, there were significant gains between pre-tests and post-tests in the teachers' confidence to teach sciences, information technology and the home language. Attitudes to science teaching remain stable with the exception of an improvement in the rating of the use of information technology (Table 2).

Table 2. Overall confidence and attitude pre-test and post-test results for the three projects

\begin{tabular}{|c|c|c|c|c|c|c|}
\hline & \multicolumn{3}{|c|}{ Pre-test } & \multicolumn{3}{|c|}{ Post-test } \\
\hline & $\begin{array}{l}\text { Mean } \\
\text { score/ } \\
\text { item }\end{array}$ & $\begin{array}{l}\text { Std. } \\
\text { dev. }\end{array}$ & $\mathbf{n}$ & $\begin{array}{c}\text { Mean } \\
\text { score/ } \\
\text { item }\end{array}$ & $\begin{array}{l}\text { Std. } \\
\text { dev. }\end{array}$ & $\mathbf{n}$ \\
\hline \multicolumn{7}{|l|}{ Confidence in teaching } \\
\hline Home language & 4.14 & 0.75 & 170 & $4.25^{\mathrm{s}}$ & 0.81 & 170 \\
\hline Mathematics & 4.21 & 0.81 & 167 & 4.31 & 0.71 & 167 \\
\hline Science & 3.52 & 0.94 & 177 & $3.98^{\mathrm{mm}}$ & 0.78 & 177 \\
\hline Information technology & 3.03 & 1.20 & 163 & $3.29^{\mathrm{ss}}$ & 1.10 & 163 \\
\hline Biology & 3.80 & 0.85 & 172 & 4.05 ss & 0.81 & 172 \\
\hline Chemistry & 3.21 & 1.07 & 170 & $3.69 \mathrm{~mm}$ & 0.91 & 170 \\
\hline Physics & 3.09 & 1.07 & 169 & 3.54 ss & 1.05 & 169 \\
\hline \multicolumn{7}{|l|}{ Attitudinal scales } \\
\hline Social dimension to science learning & 4.54 & 0.54 & 189 & 4.60 & 0.48 & 189 \\
\hline $\begin{array}{l}\text { Continuous teacher professional } \\
\text { development }\end{array}$ & 4.32 & 0.64 & 185 & 4.35 & 0.60 & 185 \\
\hline Testing & 3.77 & 0.79 & 184 & 3.85 & 0.77 & 184 \\
\hline Quality support to science learners & 4.06 & 0.54 & 173 & 4.12 & 0.44 & 173 \\
\hline Observational, experimental science & 4.32 & 0.51 & 186 & 4.39 & 0.49 & 186 \\
\hline \multicolumn{7}{|c|}{ Unallocated attitude items: Views of the importance of } \\
\hline $\begin{array}{l}\text { Being able to demonstrate } \\
\text { experiments }\end{array}$ & 4.31 & 0.79 & 193 & 4.21 & 0.84 & 193 \\
\hline $\begin{array}{l}\text { Encouraging pupils to guess and } \\
\text { speculate }\end{array}$ & 4.67 & 0.59 & 193 & 4.72 & 0.57 & 193 \\
\hline Using a range of questioning skills & 4.30 & 0.75 & 180 & 4.39 & 0.70 & 180 \\
\hline $\begin{array}{l}\text { Arranging for pupils to work in } \\
\text { groups }\end{array}$ & 4.26 & 0.85 & 192 & 4.24 & 0.83 & 192 \\
\hline Frequently revising earlier learning & 4.22 & 0.74 & 190 & 4.27 & 0.75 & 190 \\
\hline Using information technology & 3.70 & 0.90 & 178 & $3.92^{\mathrm{ss}}$ & 0.83 & 178 \\
\hline $\begin{array}{l}\text { Making sure there are enough } \\
\text { learning resources }\end{array}$ & 4.50 & 0.68 & 186 & 4.50 & 0.67 & 186 \\
\hline
\end{tabular}


Evaluating science books and resources

${ }^{\mathrm{mm}}$ Sig gain on post-test, $\mathrm{p}<1 \%$, Wilcoxon matched pairs, medium effect size

${ }^{\text {ss }}$ Sig gain on post-test, $\mathrm{p}<1 \%$, Wilcoxon pairs, small effect size

${ }^{s}$ Sig gain on post-test, $\mathrm{p}<5 \%$, Wilcoxon pairs, small effect size

The AstraZeneca sample differs from the overall pattern in that there was an insignificant change in the confidence in teaching English. Similarly, when examined alone the Pollen sample of teachers showed no significant change in teaching their home language. In addition, the Pollen teachers' confidence in teaching biology did not show a significant change. The Oak Hill sample is very small $(\mathrm{n}=6$ or 7 for test/re-test) and shows no significant changes apart from the item about encouraging pupils to guess and speculate, which increased from 3.57 to 4.43 (std.dev.0.54 and $n=7, p<5 \%$, large effect size).

\section{Teacher types}

The overall pattern masks the fact that individual teachers responded to the in-service in very different ways. Using 120 teachers with complete data sets, cluster analysis separated the teachers into relatively homogeneous types who differed significantly on the variables relating to confidence in teaching science and attitudes. Three main types were identified:

1. Science unsures

2. Holistic improvers

3. High level, positive progressives

\section{Science unsures}

There is only a small group of seven teachers in the first type. Their mean scores are below those of other teachers in all of the variables. They had very low initial confidence in physics and chemistry, differing from the means for the other teachers with large effect sizes, which showed no significant improvement by the time of the post-test. Their initial low attitude scores (though still positive) on the Social dimension to science learning, Quality professional support to science learners and Observational, experimental science also show no significant change by post-test and remain below the average (Table 3). There were significant deteriorations in the mean scores for the importance of individual items 'Being able to demonstrate experiments' and 'Encouraging pupils to guess and speculate'. Their view was that the in-service 
was not successful, as their attitudes to Continuous teacher professional development dropped significantly below average after the projects.

Five of the seven Unsures were part of the Pollen project and two came from the AstraZeneca Project. The one German teacher in this group was interviewed. She had never taught science before despite having taught for more than 30 years. She only took part in two in-service sessions and found the in-service handbooks a little confusing in parts. When she was interviewed she gave the impression that teaching science was a burden to her, as it required extra input from her that she was unwilling to give. The other four Pollen teachers came from Belgium, where teachers are mainly non-graduates in a wide range of schools, with varying philosophies and status, so that it is not possible to impose strict curriculum guidelines that might give structure. Therefore, it appears that in a few cases this in-service did not have any impact because it did not last long enough to overcome both weaknesses in science teaching and science knowledge.

Table 3. Science unsures $(n=7)$ pre-test and post-test changes in confidence and attitudinal scale scores

\begin{tabular}{|l|c|c|c|c|}
\hline \multirow{2}{*}{ Attitude scale/item } & \multicolumn{2}{c|}{ Pre-test } & \multicolumn{2}{c|}{ Post-test } \\
\cline { 2 - 5 } & $\begin{array}{c}\text { Mean } \\
\text { score/ } \\
\text { item }\end{array}$ & Std. dev. & $\begin{array}{c}\text { Mean } \\
\text { score/ } \\
\text { item }\end{array}$ & Std. dev. \\
\hline Confidence in teaching & 4.43 & 0.79 & 4.43 & 0.98 \\
\hline Home language & 4.00 & 1.00 & 4.00 & 1.00 \\
\hline Mathematics & 2.71 & 1.11 & 2.57 & 0.54 \\
\hline Science & 2.86 & 0.35 & 3.29 & 1.11 \\
\hline Information technology & 3.00 & 0.82 & 3.43 & 0.79 \\
\hline Biology & 1.86 & 0.90 & 2.29 & 1.11 \\
\hline Chemistry & 2.14 & 1.22 & 2.14 & 1.22 \\
\hline Physics & & & & \\
\hline Attitudinal scales & 3.67 & 0.51 & 37.6 & 0.76 \\
\hline Social dimension to science learning & 4.00 & 0.47 & 3.86 & 0.33 \\
\hline $\begin{array}{l}\text { Continuous teacher professional } \\
\text { development }\end{array}$ & 3.57 & 0.9 & 3.43 & 0.53 \\
\hline Testing & 3.49 & 0.61 & 3.41 & 0.5 \\
\hline Quality support to science learners & 3.82 & 0.49 & 3.57 & 0.4 \\
\hline Observational, experimental science & & &
\end{tabular}

\section{Holistic improvers}

This group of 41 teachers generally had initial attitude scores above the mid-points of the scales, although their scores are below 
average in comparison with the whole group. While their attitudes at post-test show no significant change, they show a significant increase in teaching confidence on all of the confidence scales (Table 4). In all three sciences the improvements in confidence for these teachers are much greater than those for High level progressive teachers. The growth in all-round confidence points towards a holistic improvement in classroom performance. Participation in the in-service appears to have had a positive effect on all of their teaching.

The Holistic improvers are dominated by 26 AstraZeneca teachers and 4 from Oak Hill Primary, all of whom came from schools that were identified as having poor science results. Therefore, it might be expected that these teachers would have poorer attitudes compared to the majority of Pollen teachers, who typically volunteered to take part in the innovative European project. This group of Holistic improvers appears to represent an early developmental stage in how teachers respond to in-service.

In addition, 7 of the 11 Pollen teachers in this group came from England. It was noticeable that England was one of the Pollen countries where there were generally poorer overall attitudes. This appeared to be related to a closely controlled and demanding science curriculum, where pupils were tested and teachers inspected. Typically one English teacher said "I think [the Pollen project] has a massive impact. Of all of the professional opportunities I've had, it's been about the best. It's changed my view of what I am doing in the classroom and had a massive influence on my teaching... I felt my class weren't as motivated, but that's nothing to do with the Pollen project, that's to do with other issues... we're so desperate to get our SATs (national tests for pupils) up, and the kids have kind of picked up on that and it's less motivating to work under those conditions." The teachers' ability to apply their new ideas in the classroom is clearly influenced by a number of factors that relate not only to the educational system they are working in but also to their personal motivation and that of their pupils. 
Table 4. Holistic Improvers $(n=41)$ pre-test and post-test changes in confidence and attitudinal scale scores $(n=41)$

\begin{tabular}{|l|c|c|c|c|}
\hline \multirow{2}{*}{\multicolumn{2}{|c|}{ Attitude scale/item }} & \multicolumn{2}{c|}{ Pre-test } & \multicolumn{2}{c|}{ Post-test } \\
\cline { 2 - 5 } & $\begin{array}{c}\text { Mean } \\
\text { score/item }\end{array}$ & Std. dev. & score/item & Std. dev. \\
\hline Confidence in teaching & 3.76 & 0.54 & $4.07^{\text {ss }}$ & 0.52 \\
\hline Home language & 3.83 & 0.92 & $4.12^{\mathrm{s}}$ & 0.60 \\
\hline Mathematics & 3.20 & 0.93 & $3.95^{\mathrm{Il}}$ & 0.71 \\
\hline Science & 2.59 & 1.31 & $3.00^{\mathrm{mm}}$ & 1.05 \\
\hline Information technology & 3.59 & 0.77 & $4.05^{\mathrm{mm}}$ & 0.59 \\
\hline Biology & 3.29 & 0.84 & $3.85^{\mathrm{Il}}$ & 0.76 \\
\hline Chemistry & 3.20 & 0.84 & $3.71^{\mathrm{mm}}$ & 0.93 \\
\hline Physics & \multicolumn{3}{|c}{} \\
\hline Attitudinal scales & 4.32 & 0.38 & 4.39 & 0.41 \\
\hline Social dimension to science learning & 3.89 & 0.63 & 3.95 & 0.50 \\
\hline $\begin{array}{l}\text { Continuous teacher professional } \\
\text { development }\end{array}$ & 3.57 & 0.5 & 3.57 & 0.53 \\
\hline Testing & 3.82 & 0.35 & 3.90 & 0.33 \\
\hline Quality support to science learners & 4.15 & 0.46 & 4.20 & 0.40 \\
\hline Observational, experimental science & & &
\end{tabular}

${ }^{11}$ Sig gain on post-test, $\mathrm{p}<1 \%$, Wilcoxon pairs, large effect size ${ }^{\mathrm{mm}}$ Sig gain on post-test, $\mathrm{p}<1 \%$, Wilcoxon pairs, medium effect size

${ }^{\mathrm{s}}$ Sig gain on post-test, $\mathrm{p}<5 \%$, Wilcoxon pairs, small effect size

${ }^{\text {ss }}$ Sig gain on post-test, $\mathrm{p}<1 \%$, Wilcoxon pairs, small effect size

\section{High level, positive progressives}

64 teachers were in the third group based on the cluster analysis. 58 of these teachers were from the Pollen project, 4 from AstraZeneca and 2 from Oak Hill Primary. They had above average (for the survey sample) initial science confidence and were more confident with regard to mathematics and information technology than the other two groups. The in-service appeared to boost their confidence in physics and chemistry but not biology, in which their confidence was already relatively high (Table 5). They also had significantly above-average attitude scores on all five attitude scales at both pre-test and post-test. Following in-service there is a significant improvement on the Social dimension to science learning scale.

While further cluster analysis of the Holistic improvers primarily relates to variations of increased confidence in teaching one or more science subjects, additional cluster analysis of High level, positive progressives indicates more complex variations with respect to confidence and/or attitudes. This latter type can be split into three subgroups: 
- $\quad$ One subset had significantly higher confidence scores in teaching all three sciences and information technology. Confidence scores remained high but did not show improvement as the others caught up. These teachers appeared to consolidate their pedagogical learning as they showed significantly higher attitude changes with regard to Observational, experimental science.

- The second subgroup showed significantly high stable attitudes while their science teaching confidence was only average. They also scored highly on unallocated items that broadly express attributes of good pedagogical practice. Their results indicate that they were well motivated towards science but lacked high subject expertise.

- $\quad$ The third subset is exclusively Pollen teachers and showed a significant improvement on the Social dimension to science learning scale. They appeared to have expertise in mathematics and information technology initially and gained confidence teaching physics and chemistry. While their attitudes were average for High level positive progressives, this subgroup were strong believers in group work and in encouraging pupils to predict and speculate. They responded well to the specific Pollen foci on developing pupils' investigative skills and showing how science relates to everyday life. They appear to have had sufficient science knowledge and investigative skills to branch out to be more creative. One Swedish teacher in this group illustrated her ability to make links beyond the classroom when she said 'When we grow seeds we go out into the woods and parks to look for things. When we are working with chemistry we discuss what they do in their own kitchen... and when we work with electricity we help them look for things at home.'

Nine countries involved in Pollen have representatives in the High level progressives group. The interviews of this group confirm the generally high initial confidence and positive response to the in-service and the subset analysis. The one English teacher and most of the seven German teachers of this type who were interviewed were originally secondary science teachers who were now teaching science to primary aged pupils. They knew that while much of their science knowledge was good, they needed to develop better pedagogical skills suitable for 
younger pupils. In contrast, other German teachers were talented primary teachers but needed support in their science knowledge. Unlike the Science unsures, these teachers had expertise that gave them confidence, or efficacy, to build on either science or mathematical knowledge, or pedagogical expertise. To make the most of an in-service programme requiring considerable application in the classroom teachers need initial self-efficacy or self-confidence in their basic skills.

Table 5. High Level, Positive Progressives $(n=64)$ pre-test and posttest changes in confidence and attitudinal scale scores

\begin{tabular}{|l|c|c|c|c|}
\hline \multirow{2}{*}{ Attitude scale/item } & \multicolumn{2}{c|}{ Pre-test } & \multicolumn{2}{c|}{ Post-test } \\
\cline { 2 - 5 } & $\begin{array}{c}\text { Mean } \\
\text { score/item }\end{array}$ & $\begin{array}{c}\text { Std. } \\
\text { dev. }\end{array}$ & $\begin{array}{c}\text { Mean } \\
\text { score/item }\end{array}$ & $\begin{array}{c}\text { Std. } \\
\text { dev. }\end{array}$ \\
\hline Confidence in teaching & 4.17 & 0.81 & 4.14 & 0.89 \\
\hline Home language & 4.48 & 0.50 & 4.41 & 0.71 \\
\hline Mathematics & 3.88 & 0.85 & $4.13^{\text {s }}$ & 0.75 \\
\hline Science & 3.45 & 1.01 & 3.55 & 1.11 \\
\hline Information technology & 4.09 & 0.77 & 4.11 & 0.88 \\
\hline Biology & 3.35 & 1.10 & $3.71^{\text {ss }}$ & 0.99 \\
\hline Chemistry & 3.24 & 1.07 & $3.56^{\text {ss }}$ & 1.05 \\
\hline Physics & \multicolumn{3}{|c}{} \\
\hline Attitudinal scales & 4.71 & 0.37 & $4.82^{\text {s }}$ & 0.28 \\
\hline Social dimension to science learning & 4.48 & 0.47 & 4.56 & 0.46 \\
\hline $\begin{array}{l}\text { Continuous teacher professional } \\
\text { development }\end{array}$ & 4.03 & 0.7 & 4.08 & 0.70 \\
\hline Testing & 4.27 & 0.41 & 4.28 & 0.39 \\
\hline Quality support to science learners & 4.41 & 0.48 & 4.52 & 0.47 \\
\hline Observational, experimental science &
\end{tabular}

${ }^{s}$ Sig gain on post-test, $\mathrm{p}<5 \%$, Wilcoxon pairs, small effect size

ss Sig gain on post-test, $\mathrm{p}<1 \%$, Wilcoxon pairs, small effect size

\section{Developmental stages of teachers' changing practice following in-service}

It can be seen from the above account that there were major differences in initial teachers' attitudes and efficacy/self-confidence before the in-service and in their subsequent development. The observations and interviews enable us to relate these and to suggest possible stages of impact in the classroom. These stages extend Joyce and Showers's (1980) developmental levels of impact that might be expected during in-service. Their first three levels primarily focus on teachers' personal skills and conceptual knowledge, while the fourth focuses on classroom practice. Their stages are: 
1. Awareness - where the learner realises the importance of an area and begins to focus on it. For example, the teacher recognises the value of a structure for supporting pupils' investigative skills.

2. Concepts and organised knowledge, which involves both content knowledge and an appreciation of how learners develop cognitive knowledge.

3. Principles and skills that provide the tools for action, such as the pedagogy required to help pupils to collect and organise data, and to build and test concepts.

4. Application and problem solving, when the teacher is able to transfer their new expertise to the classroom, where the new teaching strategy is integrated into the teachers' repertoire and style.

Many Science unsures include teachers who are still at Joyce and Showers's first three stages. They need substantial and sustained inservice focusing on their personal science knowledge and investigative skills. However, there is also a group of Science unsures teachers who appear to have the basic science knowledge and skills but are not motivated to apply them. The Holistic improvers have some confidence, which needs to be built up to a level where the teacher is motivated to change his/her practice. Although this motivation might be supported by school managers, colleagues and trainers, positive pupils' reactions appear to be a major factor in development. The High level, positive progressives have the advantage of initial high levels of confidence in either science knowledge or pedagogy. This generally allows them to be more creative in the classroom. However, despite the teacher becoming even more positive, if their pedagogical skills do not reach a stage where pupils are intellectually stimulated improvement in the classroom will be slow. Harlen (1997) states that teachers need pedagogical strategies for handling children's questions and turning them to the advantage of investigative learning at their finger tips, but they also need sources of information and a level of general understanding that facilitates the quick and effective use of these sources.

Taking account of these teacher types, as well as interviews and observations, nine developmental stages overlapping and extending Joyce and Showers's fourth step are suggested: 
1. Lacks the motivation to apply the knowledge and expertise to the classroom. For example, Margaret from Oak Hill, while being proud that she had carried out two investigations in her class, did not like the feeling of losing control. Consequently, she avoided doing all of the practical work herself and asked a classroom assistant to do it with small groups outside her classroom area. Margaret was about to retire so had little reason to change her practice.

2. Self-confidence increases so that the teachers improve their attitude to science but appear to make limited effective change in their class. Grace and Wendy are examples of teachers who have either expertise in pedagogy or science knowledge but not both. It is only when both are established that change is seen in the classroom. Before the in-service, Grace, a Holistic Improver at Oak Hill, said that she did not enjoy science at all because she felt inadequate. She took an active part in the in-service, which had a very positive effect on her self-confidence and attitudes. However, she did not do any 'pure' investigations. She did include some science concepts alongside her literacy-based story-telling activities. Language was her strength and this provided the beginning of a basis to build up her confidence to teach science. In contrast, as a secondary science teacher Wendy (Pollen) was scientifically knowledgeable. She also noticeably enjoyed the social and intellectual stimulation of the in-service, with the effect that her improved confidence and attitudinal scores classified her as a High Level Progressive. However, while she applied her new ideas in the classroom, the activities were too easy for the pupils, resulting in her pupils showing significant attitudinal falls with regard to liking science in school. (In the year since the administration of the questionnaires, in-service continued and Wendy improved her pedagogical skills and is now consistently providing stimulating investigative activities.)

3. Teachers replicate activities shown in in-service sessions. During the in-service programme, the teachers were rather cautious at 
first and tended to be fairly directive with the pupils because the activities were new to them. Usually the children reacted with increased interest and behaved well, proving that they could respond well to this approach. The pupils' positive response increased the teachers' self-confidence and desire to continue with the new approach. The close relationship between the type of activity and the pupils' response was seen in Louise's (Pollen) class. Louise tried out several activities that involved the community but she did not develop as many practical investigative activities as she might have. Her pupils' attitudes to science's value in society increased significantly, but their views about doing investigations did not. This indicated that they were only responding positively to this new rather narrow focus. As pupils became enthusiastic, Louise's confidence in teaching science showed a strong improvement.

4. Activities are repeated and adjusted to cater for individual children's needs and/or the situation in the class. Angela, a Holistic improver from Oak Hill, lacked confidence and actively disliked science. She had avoided teaching any science by taking colleagues' physical education classes, as she had very poor science knowledge. She was initially very reluctant to participate in the first in-service session, but was drawn into the practical nature of the activities. She did two of the activities from this first in-service in her class and was pleasantly surprised by the children's response, and by the fact that it had been easy for her. After this initial success, Angela was keener to use the in-service to plan lessons, and started to creatively adapt each activity to fit the needs of the pupils. As the teachers received positive reactions from the pupils they became more daring and took greater risks, thus starting to add and develop ideas from the in-service within the same topic. As their confidence increased they moved towards a greater partnership with the pupils, who were given more independence and say in the activities.

5. The principles shown in the in-service are applied in a new topic/age group. One Pollen teacher, Tamara from Broadside 
School, applied in-service ideas to the whole school age range. The visiting tutor reported that she had observed lessons for 5-year-olds to 11-year-olds where Tamara had skilfully adapted the basic principles from the in-service to meet the objectives of all or the age groups, such as enabling the 11-year-olds to do investigations about light so that they could teach 6-year-olds using appropriate language for the younger pupils.

6. There is an increased sharing of work within the school with other colleagues. Towards the end of the in-service programme, the two Holistic improvers and Tamara from Broadside collaborated to promote the Pollen ideas in their classes, as well as at whole-school assemblies and staff meetings. These whole school activities showed that children could respond well to independent investigative work. Tamara persuaded other teachers who had not attended the in-service to let her plan and demonstrate lessons that they had been reluctant to try as they felt the children would find the work too difficult. When they saw Pollen-type lessons in action and witnessed the benefits first-hand, they were encouraged to continue this approach. The three teachers taking the in-service were not deterred by the strong initial resistance and eventually managed to get other staff members interested. It was clearly advantageous that the group of three teachers had attended the in-service together and were able to give each other moral support.

7. Changes are seen in whole-school planning. Year groups and classes make partial changes to include the new approach.

Observers noted that in a few English Pollen schools at the end of the three years of the Pollen project, course participants had started to make changes in collaborative planning affecting several teachers. For example, in one school the traditional topics were rearranged so that logical links could be made more easily between science and other subjects in order to show how science is relevant in many situations. 
8. Whole-school change of approach. None of the English schools in the Pollen project had, after three years, changed their whole-school plans to optimise a cross-curricular hands-on investigative approach, although some were getting close to that stage. The majority of the teachers in the school, including those who had not attended the in-service programme, needed to be confident and able to teach investigative science. It was clear that there would also need to be changes in timetabling, which would affect other subjects. In addition, changes in organisation were often required to ensure the availability of equipment. Furthermore, the possibility for such a major change only occurs once a year when major planning for the next academic year takes place.

\section{Conclusion}

Teacher questionnaire results were combined and compared across three projects that have taken place in Leicester, England and other European countries over the past ten years. At the broad project level, there were few differences between the AstraZeneca, Oak Hill Primary and Pollen samples. Overall, there were significant gains in the confidence of teaching sciences, information technology and the home language. Attitudes to science teaching remained stable with the exception of an improvement in the rating of information technology use.

However, the overall evaluation of an in-service programme can only give a superficial view, as results are made up of a variety of responses. Using cluster analysis, three major teacher types were identified:

- $\quad$ Science unsures, a small group with low attitude scores and little confidence, who showed no response to the innovation;

- Holistic improvers, who showed the largest improvement in science teaching confidence as well as becoming more confident across the curriculum. Their average attitudes to science teaching remained stable throughout; and

- High level, positive progressives, who were the largest group. They were very positive towards science teaching throughout and showed gains in confidence in teaching physics and chemistry, as well as in ways of making links between their science activities and everyday social activities. 
At a more precise level of analysis, the second and third teacher types were found to comprise sub-types that differ significantly from one another, indicating that the AstraZenca and Pollen projects had drawn on different teacher-type profiles at the outset. Observations and interviews provided an opportunity to build on the cluster types in order to develop a possible developmental model that teachers go though before new practice is established first in the classroom and then in the whole school.

Cluster analysis found that the teachers' starting point of development was strongly affected by their attitudes to science, as well as by their efficacy or self-confidence in their science knowledge and scientific pedagogical skills. While it is not surprising that inexperienced teachers need a longer in-service programme and many opportunities to practice their new skills, the speed of each teacher's development during the in-service did not depend entirely on where they started. While initial self-confidence was important, motivation prompted by personal success and a positive response from the pupils were key factors. This finding generally supports the view of researchers into teacher efficacy that feedback about success in applying new skills after in-service is very important (e.g., Guskey, 1986). However, while a positive response from peers and management, as well as results of attainment, do partly provide this feedback, these researchers do not appear to have recognised pupil enthusiasm as also being very important.

Initial self-confidence in both science knowledge and the pedagogy of teaching science are major factors. Without both, improvements in the classroom may not occur or may even have a negative effect. Once the teachers had enough confidence and ability to successfully apply their new knowledge and skills in the classroom the pupils' response was very important. If the teachers were able to present the lesson satisfactorily the children usually reacted with increased interest and behaved well. This motivated teachers to continue the new approach. Providing sufficiently demanding tasks by encouraging independence and making conceptual challenges appears important in improving pupils' attitudes. This relates to Pell and Jarvis's (2001) finding that pupils' enthusiasm for science declines if they perceive it to be too easy.

Once having overcome the first hurdle of introducing the new activities successfully, the teachers continued to replicate activities demonstrated in the in-service. This process was again usually encouraged by the response of their pupils, but also by the response of 
colleagues and managers in the school. Some teachers increasingly became more daring and took greater risks to add/develop ideas from the in-service. As they gained greater confidence they moved towards a greater partnership with the pupils, who were given more independence. It was clear that a feedback cycle needed to be in place: the provision of stimulating hands-on science that excited pupils increased teachers' efficacy to prompt more demanding and stimulating tasks for pupils and so on.

Development was initially focused on individual teachers' classrooms. Teachers did not involve other colleagues in their school until they felt confident in themselves and their pupils. Once this stage was achieved teachers were keen to share their new skills with colleagues and in so doing gained further kudos and confidence. Generally effective whole-school dissemination did not appear to be feasible until this point. Of course, colleagues in their school also needed to go through a developmental process. This was supported in a variety of ways, such as informal peer mentoring, internally run staff in-service sessions, visits by project tutors and trial whole-school activities. For example, some English Pollen schools tried 'Creative Days' or one 'Creative Unit' a year alongside more standard science units. To enable a whole school to change will take several years, particularly as major planning changes are only made once a year.

When designing new in-service programmes it is important to assess teachers' initial level of self-confidence in both science subject knowledge and science pedagogy, such as Inquiry-Based Science Education (IBSE) skills. These need to be addressed first by teachers doing investigations for themselves and having time to understand the underlying science concepts. In all three projects teachers valued trying and extending the investigations that they would later give to the pupils. This stage may take some considerable time if the teachers' original expertise is low.

Encouraging teachers to try out new activities in the classroom is a major challenge, but it is essential in order to trigger the feedback loop of teacher and pupil motivation. Strategies that have been found to work in these three projects include having two or three teachers from the same school taking the in-service together so that they give each other peer support, as well as enabling trainers or mentors to visit classrooms to participate and to support the teacher, not to assess him/ her. Teachers found it difficult not to try the activities when they were visited by their mentor. The mentors were also able to give some advice 
on ensuring that the level of difficulty was appropriate. In England, the visiting mentors also wrote short reports from each visit, illustrated with photographs, in order to produce high quality glossy booklets (www.scicentre.org.uk) to show the teachers that their work was valued. The booklets were also designed to keep school principals and governors informed about the project, as in-service was also most effective in schools where senior managers fully understood its potential for raising standards and were committed to using it as a key driver for school improvement (OFSTED, 2006).

Funding for this research originally came from AstraZeneca Science Teaching Trust and the European Commission Pollen Seed Cities: A Community Approach for a Sustainable Growth of Science Education in Europe.

\section{References}

Aron, A., \& Aron, E. N. (1999). Statistics for psychology. New Jersey: Prentice Hall. Bandura, A. (1977). Self-efficacy: Towards a unifying theory of behavioural change. Psychological Review, 84(2), 191-215.

Blatchford, P. (1992). Children's attitudes to work at 11 years. Educational Studies, 18, $107-118$.

den Brook, P., Fisher, D. \& Scott, R. (2005). The importance of teacher interpersonal behaviour for student attitudes in Brunei primary science classes. International Journal of Science Education, 27(7), 3,765-779.

Duschl, R. A., Schweingruber H. A., \& Shouse A.W. (Eds.) (2007). Taking science to school: Learning and teaching science in grades K-8. Washington, DC: National Academies Press. Gago, J. M. (2004). Increasing human resources for science and technology in Europe. Brussels EC conference 'Europe needs more scientists' 2 April.

Germann, P. J. (1988). Development of the attitude toward science in school assessment and its use to investigate the relationship between science achievement and attitude toward science in school. Journal of Research in Science Teaching, 25, 689-703.

Glasersfeld, E. von (1995). Radical constructivism: A way of knowing and learning. London: Falmer Press.

Guskey, T. R. (1988). Teacher efficacy, self-concept, and attitudes toward the implementation of instructional innovation. Teaching \& Teacher Education, 4(1), 63-69. Harlen, W. (1997). Primary teachers' understanding in science and its impact in the classroom. Research in Science Education, 27(3), 323-337.

Harlen, W., \& Holroyd, C. (1997). Primary teachers' understanding of concepts of science: impact on confidence and teaching. International Journal of Science Education, 19(1), 93-105.

Jarvis, T., \& Pell, A. (2002). Changes in primary boys' and girls' attitudes to school and 
science during a two-year science in-service programme. The Curriculum Journal, 13(1), 43-69.

Jarvis, T., \& Pell, A. (2004). Primary teachers' changing attitudes and cognition during a two-year science in-service programme and their effect on pupils. International Journal of Science Education, 26(14), 1787-1811.

Jarvis, T., Pell, A., \& McKeon, F. (2003). Changes in primary teachers' science knowledge and understanding during a two year in-service programme. Research in Science \& Technological Education, 21(1), 17-42.

Joyce, B., \& Showers, B. (1980). Improving in-service training: the messages of research. Educational Leadership, 37(5), 379-385.

Lee, O. (1995). Subject matter knowledge, classroom management, and instructional practices in middle school science classrooms. Journal of Research in Science Teaching, $32(4), 423-440$.

Martin, M. O., Mullis, I. V. S., \& Foy, P. (with Olson, J. F., Erberber, E., Preuschoff, C., \& Galia, J.) (2008). TIMSS 2007 International science report: Findings from IEA's trends in international mathematics and science study at the fourth and eighth grades. Chestnut Hill, MA: TIMSS \& PIRLS International Study Center, Boston College.

Office for Standards in Education (OFSTED) (2006). The logical chain: Continuing professional development in effective schools. London, HMI 2639.

Osborne, J., \& Dillon, J. (2008). Science education in Europe: Critical reflections. London: Kings College.

Osborne, J., \& Simon, S. (1996). Primary science: past and future directions. Studies in Science Education, 26, 99-147.

Park, S., \& Oliver, J. S. (2008). Revisiting the conceptualisation of pedagogical content knowledge (PCK); PCK as a conceptual tool to understand teachers as professionals.

Research in Science Education, 38, 261-284.

Pell, A., \& Jarvis, T. (2001). Developing attitude to science scales for use with children of ages from five to eleven years. International Journal in Science Education, 23(8), 847-862. Pell, A., \& Jarvis, T. (2003). Developing attitude to science scales for use with primary teachers. International Journal of Science Education, 25(10), 1273-1295.

Rocard, M. (2008). Science education now: A renewed pedagogy for the future of Europe. Brussels: European Commission.

She, H., \& Fisher, D. (2002). Teacher communication behavior and its association with students' cognitive and attitudinal outcomes in science in Taiwan. Journal of Research in Science Teaching, 39(1), 63-78.

Stein, M. K., \& Wang M. C. (1988). Teacher development and school improvement: the process of teacher change. Teaching \& Teacher Education, 4(2), 171-187.

Tschannen-Moran, M., \& Hoy, A.W. (2001). Teacher efficacy: capturing an elusive construct. Teaching and Teacher Education, 17, 783-805.

Wittrock, C. M. (1994) Generative science teaching. In P. Fensham, R. Gunstone \& R. 
White (Eds.), The Content of Science: A Constructivist Approach to Teaching and Learning. London: Falmer Press.

Woodward, C., \& Woodward N. (1998). Welsh primary school leavers' perceptions of science. Research in Science \& Technological Education, 16(1), 43-52.

Woolnough, B.E. (1990). Making choices. Oxford, UK: Oxford University Department of Educational Studies.

Youngman, M. B. (1979). Analysing social and educational research data. London: McGraw Hill. 


\section{Biographical note}

Tina JARvis is Emeritus Professor of Education at the University of Leicester and UK Coordinator of the EU Fibonacci Project: Disseminating inquiry-based science and mathematics education in Europe. Until her recent partial retirement in September 2009, she was Executive Director of the Science Learning Centre East Midlands, Pollen National Coordinator of UK Seed City of Leicester and Director of SCIcentre. Her main activity and research has been to develop and promote innovative in-service science education as well as to carry out research on factors that influence the impact of in-service training and other types of intervention to improve attitudes and understanding of science and technology.

Anthony Pell was an Associate Researcher until 2010 at the School of Education, University of Leicester. Previously he was science education consultant to the Gazankulu Government in South Africa and researcher at the University of Cambridge. He continues to do research in South Africa and Pakistan. His main interests are statistical educational research, curriculum development, physics education and science \& society studies.

Philip Hingley worked for 26 years a teacher, and then joined the Science Learning Centre East Midlands (SLCEM) at the School of Education, University of Leicester in 2004 as a qualitative researcher. He evaluates the impact of key parts of SLCEM's professional development programme. He was also part of the evaluation team for the Pollen project. 